\title{
NOZIEDZĪGI IEGŪTAS MANTAS INSTITŪTA TIESISKAIS REGULĒJUMS LATVIJAS REPUBLIKĀ STARPKARU PERIODĀ
}

\section{LEGAL REGULATION OF THE INSTITUTE OF CRIMINALLY ACQUIRED PROPERTY DURING THE INTERWAR PERIOD IN THE REPUBLIC OF LATVIA}

\section{Daira Sergejeva, Mg. iur.}

\begin{abstract}
Summary
This article provides an insight into the basic principle of the Institute of Criminally Acquired Property during the interwar period in the Republic of Latvia. It is important to mention that nowadays, until the amendments of March 4, 2021 to Section 360 of the Criminal Procedure Law was adopted, if criminally acquired property has been found on a third person and criminally acquired property has been returned to the owner or lawful possessor thereof, a third person was only entitled to compensation. On the other hand, upon the entry into force of the amendments to Section 360 of the Criminal Procedure Law, a third person, similarly to the interwar period, in exceptional cases also has the right to property that has been recognized as criminally acquired.
\end{abstract}

Atslēgvārdi: starpkaru periods, noziedzīgi iegūta manta, noziedzīgi iegūtas mantas institūts, pamatprincips.

Keywords: interwar period, criminally obtained property, institute of criminally obtained property, basic principle.

\section{Noziedzīgi iegūtas mantas institūta pamati starpkaru periodā Latvijas Republikā}

Noziedzīgi iegūtas mantas institūts, kāds tas pastāvēja Krievijas impērijā, saglabāja savu kontinuitāti Latvijas Republikā starpkaru periodā. Nule kā minēto pamato gan Latvijas Republikas Kriminālā un Civilā kasācijas departamenta pievienošanās Krievijas impērijas Valdošā senāta (pirmsreformu krievu val. Правительствующій сенать Россійской имперіи) spriedumos paustajām atzin̄ām, gan arī noziedzīgi iegūtas mantas institūta regulējošo tiesību normu tieša pārṇemšana nacionālajās tiesībās. ${ }^{1}$

${ }^{1}$ Sergejeva D. Noziedzīgi iegūtas mantas institūta izpratne starpkaru periodā. Jurista vārds, 02.03.2021., Nr. 09 (1171), 116.-117. lpp. 
Latvijas Republikā 1918. gada 6. decembrī tika pieņemts "Pagaidu nolikums par Latvijas tiesām un tiesāšanās kārtību", kas cita starpā noteica, ka "Latvijas tiesas un ar viṇām saistītās iestādes darbojas pēc tiem vietējiem un Krievijas likumiem, kādi priekš Latvijas bija spēkā līdz 24. oktobrim 1917. gadā"2. Pamatojoties uz minēto, arī turpmāk Latvijas Republikā $\overline{ }^{3}$ bija piemērojams 1903. gada 22. marta Sodu likumu krājums (pirmsreformu krievu val. Высочайше утвержденное Уголовное Уложеніе) ${ }^{4}$ un 1864. gada 20. novembra Krievijas kriminālprocesa nolikums (pirmsreformu krievu val. Высочайше утвержденный Уставъ уголовнаго судопроизводства) $)^{5}$. Turklāt gadu vēlāk 1919. gada 5. decembra sēdē Latvijas Tautas padome pieņēma likumu par agrāko Krievijas likumu spēkā atstāšanu Latvijā. ${ }^{6}$

Lai gan starpkaru periodā Tieslietu ministrijas un Saeimas kodifikācijas nodal̦as izstrādāja un vēlāk arī izdeva Latvijas Republikas Kriminālprocesa likumu un Sodu likumu, ar ko spēku zaudēja 1864. gada 20. novembra Kriminālprocesa nolikums un 1903. gada 22. marta Sodu likums, tiesību normas, kas regulēja noziedzīgi iegūtas mantas institūtu, bija palikušas saturiski nemainīgas, proti, tika veikts tikai šo normu tulkojums no 1864. gada 20. novembra Kriminālprocesa nolikuma un 1903. gada 22. marta Sodu likuma krājuma. ${ }^{7}$

Tādējādi par Latvijas Republikas starpkaru perioda noziedzīgi iegūtas mantas institūta pamatiem noteikti var uzskatīt tieši Krievijas impērijas 1903. gada 22. marta Sodu likuma krājumu un 1864. gada 20. novembra Krievijas impērijas Kriminālprocesa nolikumu, kā arī Krievijas impērijas Valdošā senāta spriedumos iekḷautās juridiskās atziṇas.

\section{Noziedzīgi iegūtas mantas jēdziens un noziedzīgi iegūtas mantas institūta pamatprincipi}

Atbilstoši Krievijas impērijas Valdošā senāta spriedumos paustajām atziṇām ${ }^{8}$, kam pilnībā pievienojās arī Latvijas Senāts starpkaru periodā, par noziedzīgi iegūtu tika uzskatīta tikai tāda manta, kas tieši bija iegūta noziedzīgā nodarījuma

2 Pagaiðu nolifums par $\mathfrak{L} a t \mathfrak{i j a} \mathfrak{s}$ teefam un teefafchanas fahrtibu (Pagaidu nolikums par Latvijas tiesām un tiesāšanās kārtību). Pagaidu Valdības Vēstnesis, 14.12.1918., Nr. 1.

3 1918. gada 6. decembra "Pagaidu nolikums par Latvijas tiesām un tiesāšanās kārtību" noteica, ka "Latgalē pagaidām atjaunojamas Krievijas Pagaidu Valdības ievestās tiesas un piepaturami tie likumi, kuri bija spēkā Krievijas Pagaidu Valdības laikā”. 1920. gada 15. martā Tautas padome izsludināja likumprojektu par 1903. gada Sodu likumu ieviešanu arī Latgalē. Sk.: Valdības Vēstnesis, 16.03.1920., Nr. 62.

4 Высочайше утвержденное Уголовное Уложеніе. 22.03.1903, № 22704. Въ: Полное собраніе законовъ Россійской имперіи. Собраніе третіе. Томъ ХХХІХ. Отдъленіе первое. 1903, № 22360-23838. Санктпетербургъ: Типографія II Отдъленія Собственной Его Императорскаго Величества Канцеляріи, 1905 , с. $175-274$.

5 Высочайше утвержденный Уставъ уголовнаго судопроизводства. 20.11.1864, № 41476. Въ: Полное собраніе законовъ Россійской имперіи. Собраніе второе. Томъ ХXXIX. Отдъленіе второе. 1864, № 41319-41641. Санктпетербургъ: Типографія II Отдъленія Собственной Его Императорскаго Величества Канцеляріи, 1867, с. 215-306.

${ }^{6}$ Latvijas Tautas padomes pirmās sesijas piektās sēdes 1918. gada 6. decembra stenogramma (Latwijas Tautas Padomes 1. fefijas 5. fehde). Latvijas Tautas padomes sēdes, 19.11.1918., Nr. 1.

7 Sk., piemēram: Законъ о согласованіи Судебныхъ Уставовъ съ Новымъ Уголовнымъ Уложеніемъ 1933 г. Въстникъ русскаго юридическаго общъства: законъ и судъ, 1933, № 7 (37). Книга: Въстникъ русскаго юридическаго общъства: законъ и судъ. 1929-1938. Томъ III. 1933. Рига: Факсимильное изданіе, 2000, с. 751-752.

8 РБшенія Общаго Собранія Кассационныхъ съ участіемъ Перваго и Второго Департаментовъ Правительствующаго Сената. 1910. Санктпетербургъ: Общественная Польза, 1911, с. 77-81. 
rezultātā. Latvijas Senāta Kriminālais kasācijas departaments skaidroja, ka "[a]tzīt par iegūtu ar noziedzīgu nodarijumu var tikai tādu lietu, kura ar šo nodarījumu izṇemta no viṇa saimnieka faktiskās valdī̌sanas"9.

Par iegūtām ar noziedzīgu nodarījumu atzina tikai tādas lietas, "kuras piesavinātas, atṇemtas un vispār iegūtas ar noziegumu"10. Pie šādām lietām tika pieskaitīti arī prettiesiski saņemtie materiālie labumi, kukuḷi, kā arī, neievērojot noteikto kārtību (bez atḷaujas), vāktie ziedojumi. ${ }^{11}$ Jāpiebilst, ka materiālie labumi, kukuḷi un prettiesiski vāktie ziedojumi pamatā bija pakḷauti konfiskācijai, taču, ja materiālie labumi, kukuḷi tika iegūti izspiešanas rezultātā, tie bija atdodami tam, no kā tie izspiesti. ${ }^{12}$ Savukārt, ja apsūdzētajam, vācot ziedojumus, nebija l̦auna nolūka - ziedojumu vākšanas mērḳis bija patiess, tad ziedojumi tika nodoti tam, kam tie tika vākti.

Pamatprincips paredzēja, ka ar noziegumu iegūtas mantas ir paḳ̣autas atgriešanai cietušajam neatkarīgi no tā, vai šis mantas bija izņemtas no personas, kas ar tiesas spriedumu tika atzìta par vainīgu, vai - no personas, kas absolūti nav saistīta ar noziegumu, kura rezultātā manta tika izṇemta no saimnieka faktiskās valdī̌sanas. ${ }^{13}$ Šāda nostāja bija arī tiesām, skatot civiltiesiskus strīdus par mantu, kas cietušajam atṇemta ar noziedzīgu nodarỉjumu, proti, "[t]āda manta pie paša nozieguma atklāšanas resp. mantas atrašanas ir neatliekami tūliṇ atdodama îpašniekam, neskatoties uz to, kura rokās manta atradusies atṇemšanas brīdī - pie paša noziedznieka resp[ektīvi] tā dalībnieka vai pie trešās personas, kura noziegumā nav nekādu dalību ņēmusi. Tas ir viscaur un vispār atzìts un pieṇemts tiesisks princips"14.

Turklāt tiesām bija pienākums atgriezt cietušajam ar noziegumu atņemtās mantas arī apsūdzētā attaisnošanas vai lietas izbeigšanas vainīgā nenoskaidrošanas vai pierādījumu nepietiekamības dēl gadījumos, ${ }^{15}$ ievērojot vienu priekšnosacījumu - nodarījums, kā rezultātā manta tika atņemta, atzìts par noziedzīgu. ${ }^{16}$ Savukārt, ja "apsūdzētā darbībā tiesa neatrod nozieguma pazīmju, atṇemtās mantas nododamas atpakal personai, no kuras tās atṇemtas". ${ }^{17}$

Taču jāuzsver, ka 1864. gada 20. novembra Kriminālprocesa nolikuma 778. pants, attiecīgi arī 1939. gada Kriminālprocesa likuma ${ }^{18}$ 790. pants paredzēja

${ }^{9}$ Latvijas Senāta Kriminālā kasācijas departamenta 30.09.1927. spriedums Nr. 155 Vaškeviča lietā. Avots: Kamradziuss F. Latvijas Senāta Kriminālā Kasācijas Departamenta spriedumu tēžu pilnīgs kopojums. Aptver̦ laikmetu no 1919. g. lïdz 1928. g. 31. decembrim. Rìga: autora izdevums, 1928, 687. lpp.

10 Kamradziuss F. 1928, 738. lpp.

11 Sk. sīkāk: 1903. gada 22. marta Sodu likuma krājuma 277. pants un 661. pants, kā arī Latvijas Republikas 1933. gada 24. aprīla Sodu likuma 137. pants, 299. pants, 569. pants.

12 Latvijas Senāta Civilā kasācijas departamenta 26.02.1937. spriedums Nr. 1 lietā Jāṇa Kḷaviṇa prasībā pret Vili Leinertu. Avots: Senāta Civilā kasācijas departamenta 1937. g[ada] spriedumi.

13 Latvijas Senāta Kriminālā kasācijas departamenta 14.11.1924. lēmums Nr. 1211 Valmaṇa-Krūmiṇa lietā. Avots: Kamradziuss F. 1928, 738. lpp.

${ }^{14}$ Latvijas Senāta Civilā kasācijas departamenta 15.06.1921. spriedums Nr. 29 Jāṇa Pugas prasībā pret Miķeli Priedi lietā. Avots: Senāta Civilā Kasācijas Departamenta spriedumi: 1921.-1922. Tieslietu Ministrijas Vēstnesis, 1926, Nr. 5/6, 71.-72. lpp.

15 Latvijas Senāta Kriminālā kasācijas departamenta 22.12.1921. sprieduma Nr. 476 Gūtmaņa lietā. Avots: Kamradziuss F. 1928, 686. lpp.

16 Ръшенія Общаго Собранія Кассационныхъ. 1911, с. 77-81.

17 Lēmums Nr. 1211 Valmaņa-Krūmiṇa lietā. Avots: Kamradziuss F. 1928, 738. lpp. Sal.: Latvijas Senāta Kriminālā kasācijas departamenta 20.06.1928. lēmums Nr. 113 Vasariṇa u. c. lietā. Avots: Kamradziuss F. 1928, 739.-740. lpp.

18 Kriminālprocesa likums. Rīga: Valsts tipogrāfija, 1939. 
izṇēmumu no vispārējās kārtības, proti, ja uz noziedzīgā nodarījuma rezultātā iegūto lietu pretendēja kāda cita persona, tad jautājums bija risināms civiltiesiskā kārtā.

Latvijas Republikas Kriminālais kasācijas departaments norādīja, ka "visos gadījumos, kad pie krimināllietas iztiesāšanas figurējuši tādi lietiski pierādījumi, vai citi priekšmeti, kas iegūti caur tādu nodarījumu vai sakarā ar noziedzīgo nodarïjumu, tiesai ex officio jātaisa lēmums par tiem, likvidējot līdz ar to noziedzīgà nodarījuma sekas. Izṇēmumu no šā nosacījuma paredz vienīgi Kriminālproc[esa] [1]ik[uma] 790. pants, kas nosaka, ka gadījumos, ja uz lietām, kas iegūtas ar noziedzīgu nodarījumu, pretendē kāda trešā persona, tad tiesa l̦auj strīdniekiem noskaidrot savas tiesības civīltiesāšanas kārtībā. [L]ikums nešķiro noziedzīgus nodarījumus, bet runā vispārīgi par lietām, kas iegūtas ar noziedzīgu nodarījumu, kāds tas arī nebūtu"19.

Tādējādi saskaņā ar pamatprincipu mantas, kas cietušajam tika atņemtas ar noziegumu, tika atdotas krimināllietas ietvaros, ja nebija šaubu par paša nodarījuma noziedzīgumu un par personas tiesībām uz mantu. Pretējā gadījumā strīds par tiesībām uz mantu tika risināts civiltiesiskā kārtā.

Būtiski aplūkot tiesas nostāju, risinot jautājumus, kas saistīti ar noziedzīgi iegūtu mantu, civiltiesiskā kārtā.

\section{Noziedzīgi iegūtas mantas institūta civiltiesiskie aspekti starpkaru periodā Latvijas Republikā}

"Kustamas mantas īpašniekam nav tiesības to atprasīt no trešajām personām, ja tāda vina manta pārgājusi svešās rokās, kaut arī bez vina gribas, bet ne zādzības, krāpšanas vai citādā kriminālnoziedzības ceḷā." ${ }^{20}$ Taču jāuzsver, ka ne katra noziedzīgā nodarījuma rezultātā cietušajam atṇemtā manta vienmēr bija pēdējam atgriežama.

Piemēram, izšķirot jautājumu, "vai īpašniekam, ja viņš kādu savu kustamu lietu izīrējis un īrnieks to atsavinājis, ir tiesības šo lietu atprasìt no trešās personas", Latvijas Senāta Civilais kasācijas departaments nosprieda noraidoši. Saskaṇā ar 1864. gada Civillikuma 923. panta nosacijumiem “[i]]pašuma prasībai nav vietas, kad kustamu mantu, ko tās īpašnieks labprātīgi uzticēja svešai personai, dodot [to] aizdevumā, glabājumā, ķīā vai citā veidā, šì svešā persona nodos trešajai personai valdījumā. Šajā gadijumā ir piel̦aujams vien personisks prasījums pret to, kuram īpašnieks uzticēja savu mantu, taču nebūt ne pret trešo personu, labticīgu valdītāju"21. Tādējādi īpašuma tiesību prasība nav vēršama pret trešo personu - lietas labticīgu ieguvēju -, ja pēdējais to ieguva īpašumā no tādas personas, kurai šo lietu tās īpašnieks labprātīgi uzticēja, vai - no cita labticīga priekšgājēja. ${ }^{22}$

19 Latvijas Senāta Kriminālā kasācijas departamenta 20.05.1933. spriedums Nr. 349 Vītoliṇa lietā. Avots: Kamradziuss F. Latvijas Senāta Kriminālā Kasācijas Departamenta spriedumu tēžu pilnīgs kopojums. Aptver̦ laikmetu no 1931. g. 15. septembṛa līdz 1935. g. 15. septembrim. Rìga: autora izdevums, 1935, 83. lpp.

${ }^{20}$ Latvijas Senāta Civilā kasācijas departamenta 24.02.1921. spriedums Nr. 12 Leokadijas Visockajas prasībā pret N̦ikitu Daņilovu lietā. Avots: Senata Civilā Kasācijas Departamenta spriedumi: 1921.-1922., 17. lpp.

21 Буковскій В. Сводъ гражданскихъ узаконеній губерній Прибалтійскихъ. Съ продолженіемъ 1912-1914 г. г. и съ разъясненіями. Томъ І. Рига: Типографія Г. Гемпель, 1914, с. 391.

22 Senāta Civilā kasācijas departamenta 29.09.1938. spriedums Nr. 85 lietā Venceḷa Klīnslinga prasībā pret Jāni Bērziṇu. Avots: Valdības Vēstnesis, 16.08.1939., Nr. 183, 87.-94. lpp. 
Tomēr minētajā gadījumā, lai īpašnieks zaudētu īpašuma prasības tiesību, kumulatīvi ir jāizpildās trīs nosacījumiem: "1) kustamas mantas īpašniekam $\mathrm{n}$ [epieciešams] to labticīgi uzticēt svešai personai, kurai 2) nepieciešams nodot mantu trešās personas valdījumā, un 3) šì trešā persona, saņemot mantu valdījumā, atrodas labā ticībā"23. Iztrūkstot kaut vienam no šiem nosacījumiem, mantas sākotnējais īpašnieks saglāba īpašuma prasības tiesību, kā tas, piemēram, būtu gadījumos, kad manta, kas atrastos pie trešās personas, būtu nolaupita no mantas sākotnējā īpašnieka.

Neraugoties uz to, ka svešas kustamas mantas piesavināšanās ir krimināli sodāma noziedzīga darbība, kā rezultātā cietušais zaudē mantu, tā netiek atdota cietušajam, atņemot to labticīgam mantas ieguvējam. Cita starpā arī Latvijas Senāta Kriminālā kasācijas departamenta spriedumos Latvijas Senāta Civilais kasācijas departaments uzsvēra, ka "tas vien, ka pēc krimināllikumiem noziedzīgā cel̦ā iegūta lieta atdodama viṇas agrākam saimniekam, neizšķir jautājumu, kam uz šo lietu pieder īpašuma tiesības"24.

N̦emot vērā minēto, pamatoti var secināt, ka trešās personas bona fide $e^{25}$ iegūtās ìpašuma tiesības uz šādu citas personas piesavinātu mantu ir pasargātas arī no mantas sākotnējā īpašnieka īpašuma tiesību prasības. Taču šajā kopsakarā jāṇem vērā Latvijas Senāta Civilā kasācijas departamenta norādītais, ka trešajai personai ir pienākums pierādīt, ka tā bona fide ieguva mantu no personas, kurai tā tika uzticēta, vai ka "priekšgājēji - nepārtrauktā rindā - bona fide no uzglabātāja strīdū esošo mantu bona fide ieguvuši” 26 .

Saskaṇā ar pamatprincipu - noziedzīgā ceḷā atṇemta manta atdodama agrākajam saimniekam - to norādīja arī Latvijas Senāta Civilais kasācijas departaments, trešā persona - labticīgs mantas ieguvējs - nevar iegūt uz šādu mantu īpašuma tiesības, ${ }^{27}$ tomēr starpkaru periodā pastāvēja izṇēmumi, kas paredzēja atkāpes no pamatprincipa. Minēto skaidri arī iezīmē Latvijas Senāta Kriminālā kasācijas departamenta spriedumos paustās atziṇas, piemēram, "atzīstot no E. V. vārda izgatavotu ǵenerālpilnvaru par viltotu, Tiesu palāta līdz ar to atzinusi par nederīgām uz šās pilnvaras pamata izdotās apakšpilnvaras. Bet ņemot vērā, ka, noslēdzot darījumus ar tiesājamo V., kurš formāli rīkojies pilnvaras robežās, viṇa kontrahenti rīkojušies bona fide, Tiesu palāta [..] atstājusi šām personām noskaidrot savas tiesības, izrietošas no obligāciju izdošanas fakta un līgumiem, civiltiesā"28.

23 Буковскій В. 1914, с. 391.

${ }^{24}$ Spriedums Nr. 85 lietā Venceḷa Klīnslinga prasībā pret Jāni Bērziṇu. Avots: Valdības Vēstnesis, Nr. 183, 87.-94. lpp.

${ }^{25}$ Bona fide (latīṇu val.) - uzticoties, val̦sirdīgi, neviltoti, pēc labākās sirdsapziņas, bez jebkādiem blakusnodomiem, labticīgi.

${ }^{26}$ Latvijas Senāta Civilā kasācijas departamenta 18.12.1922. spriedums Nr. 90 lietā Richarda Faltiņa prasībā pret Pēteri Roptaḷu. Avots: Senata Civilā Kasacijas Departamenta spriedumi: 1922. Tieslietu Ministrijas Vēstnesis, 1927, Nr. 2/3, 219.-220. lpp.

27 Spriedums Nr. 29 Jāṇa Pugas prasībā pret Miḳeli Priedi lietā. Avots: Senata Civilā Kasācijas Departamenta spriedumi: 1921.-1922., 70.-71. lpp.

${ }^{28}$ Spriedums Nr. 349 Vìtoliṇa lietā. Avots: Kamradziuss F. 1935, 82.-83. lpp. 


\section{Kopsavilkums}

1. Noziedzīgi iegūtas mantas institūts, kāds tas pastāvēja Krievijas impērijā, saglabāja savu kontinuitāti Latvijas Republikā starpkaru periodā.

2. Par Latvijas Republikas starpkaru perioda noziedzīgi iegūtas mantas institūta pamatiem var uzskatìt Krievijas impērijas 1903. gada 22. marta Sodu likuma krājumu, 1864. gada 20. novembra Krievijas impērijas Kriminālprocesa nolikumu un Krievijas impērijas Valdošā senāta spriedumos atzītās juridiskās atzinas.

3. Pamatprincips paredz vienmēr noziedzīgā ceḷā atṇemtu mantu atdot atpakal tās sākotnējam saimniekam, tostarp arī gadījumos, kad mantas sākotnējais saimnieks šādu lūgumu tiesai nebija pieteicis, vai arī - kriminālprocesa izbeigšanas gadījumā, ja apsūdzētais tika attaisnots vai noziedzīgajā nodarījumā vainojamā persona nemaz netika noskaidrota.

4. Priekšnoteikums noziedzīgā ceḷā atnememtas mantas atgriešanai tās sākotnējam saimniekam bija paša nodarījuma, kā rezultātā mana tikusi atṇemta, atzīšana par noziedzīgu.

5. Gadījumos, kad uz lietām, kas iegūtas ar noziedzīgu nodarījumu, pretendēja kāda trešā persona, strīds tika skatīts civiltiesāšanās kārtībā.

6. Lai gan arì civiltiesas ievēroja tos pašus principus, uz kuriem savos spriedumos atsaucās krimināltiesas, risinot jautājumus, kas skar noziedzīgā ceḷā iegūtu mantu, pastāvēja izṇēmuma gadījumi, kad trešās personas īpašuma tiesības uz šādu mantu tika atzītas. 